\title{
Thermal Performance and Economic Analysis of 210 MWe Coal-Fired Power Plant
}

\author{
Ravinder Kumar, ${ }^{1}$ Avdhesh Kr. Sharma, ${ }^{1}$ and P. C. Tewari ${ }^{2}$ \\ ${ }^{1}$ Department of Mechanical Engineering, D.C.R University of Science and Technology, Murthal, Sonepat, India \\ ${ }^{2}$ Department of Mechanical Engineering, N.I.T Kurukshetra, Haryana, India
}

Correspondence should be addressed to Ravinder Kumar; rav.chauhan@yahoo.co.in

Received 19 September 2013; Revised 11 December 2013; Accepted 11 December 2013; Published 12 February 2014

Academic Editor: Mohammad Al-Nimr

Copyright (C) 2014 Ravinder Kumar et al. This is an open access article distributed under the Creative Commons Attribution License, which permits unrestricted use, distribution, and reproduction in any medium, provided the original work is properly cited.

\begin{abstract}
This paper presents the thermal and economic performance of a 210 MWe coal-fired power plant situated in North India. Analysis is used to predict coal consumption rate, overall thermal efficiency, mass flow rate of steam through boiler, and Net present value (NPV) of plant for given load. Thermodynamic analysis was carried out using mass and energy equations followed by empirical correlations. Predicted mass flow rate of steam, coal consumption rate, and thermal efficiency give fair agreement with plant operating data. The economic analysis includes operational activities such as equipment cost, fuel cost, operations and maintenance cost, revenue, and plant net present value. From economic point of view, the effect of condensate extraction pump redundancy on net present value is observed to be sensitive than boiler feed pump redundancy.
\end{abstract}

\section{Introduction}

Thermal power plant working is based on Rankine cycle, where the thermal efficiency of cycle can be thermodynamically improved by increasing the mean temperature of heat addition, that is, by introducing feedwater heating systems. Numerous researchers [1-3] have reported enhancement in thermal efficiency by dividing overall enthalpy equally via feedwater heaters. It was proposed by [4] that the thermodynamic performance of Rankine cycle power plant can be improved by reducing volumetric flow rate of steam. Later, researchers tried to improve the efficiency of the plant by increasing steam pressure, which resulted in degradation of the steam quality at the turbine exhaust. To overcome such problems, steam reheating was introduced after high pressure turbine exhaust, which leads to decrease of the moisture content at low-pressure turbine exhaust. The effect of reheat pressure on cycle efficiency was investigated [5]. They reported best performance of steam power plant at optimal reheat pressure. All the modifications/improvements in Rankine cycle (like feed water heating and reheating) lead to a substantial improvement in cycle efficiency. The study [6] on energy analysis of 250 MWe Hamedan steam power plant suggested that energy loss mainly occurs in the condenser.

The economic analysis of the plant has been carried out in past on the basis of initial capital investment, operating costs, annual revenue, and profit obtained. The Net present value of plant has been evaluated in the literature [7]. The equipment include steam turbine, boiler, generators, and other auxiliary components such as pumps, condensers, and so forth. Researchers reported considerable work on economic analysis using net present worth method in the various process industries. Sensitivity analysis for the capacity improvement of a combined cycle power plant (100-600 MW) concerning economic performance has been studied [8]. Economic feasibility and financial risk of refuse derived fuel (RDF) production plants have been instead evaluated on the basis of the Net present value index over a capacity range of 25$200 \mathrm{t} / \mathrm{h}$ comparing either single RDF production plants or facilities integrating also compost production and/or electricity generation [9]. The Net present value (NPV) approach was implemented to determine the economic manufacturing quantities for an unreliable production system over an infinite planning horizon [10]. The feasibility of using biomass to 


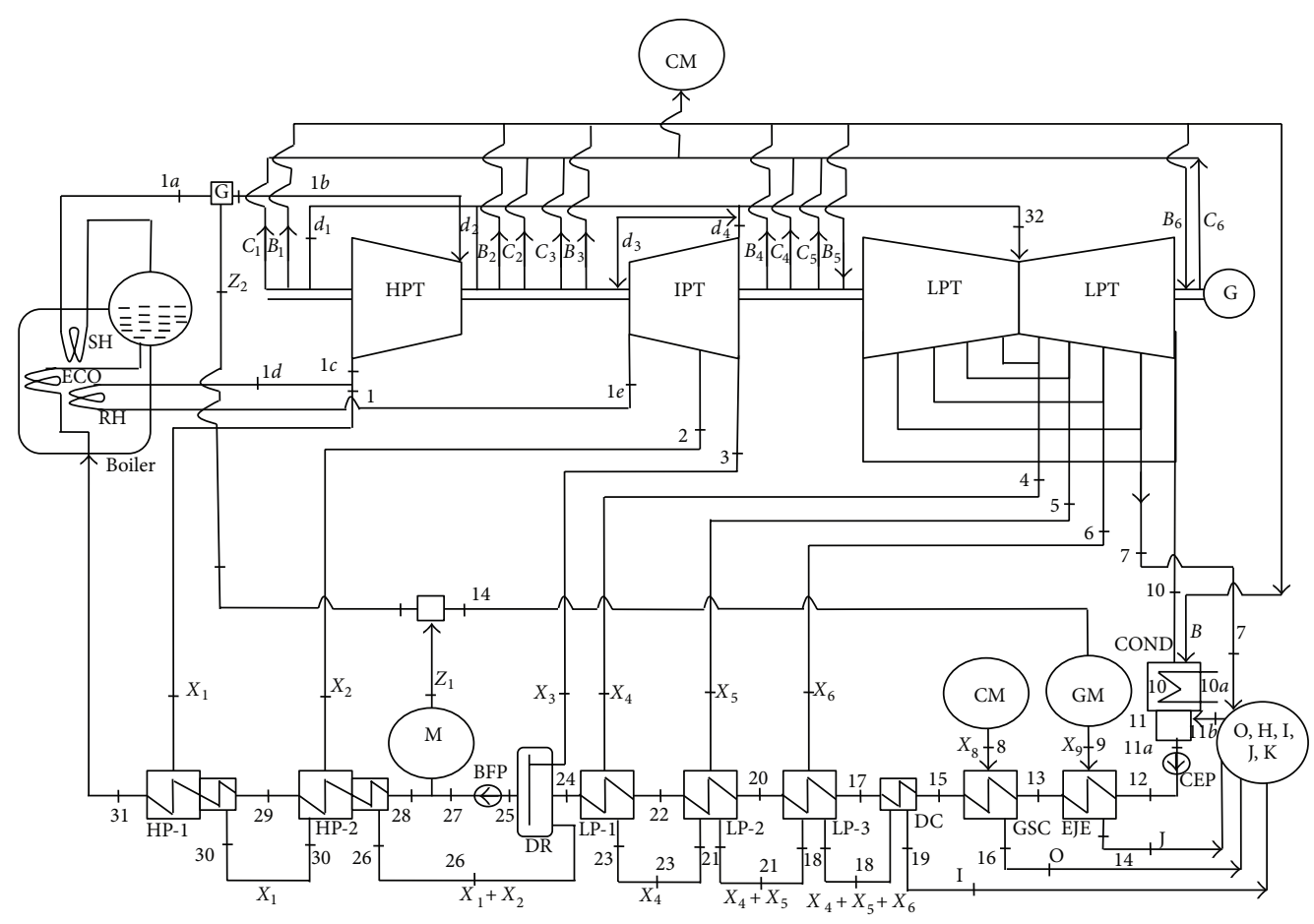

FigURE 1: Steam turbine cycle based coal-fired power plant.

provide electricity in combustion and gasification plants was investigated and evaluated [11]. The study of economic feasibility of constructing a $560 \mathrm{MW}$ coal-fired power plant in Turkey, using real options theory, was discussed [12]. A parametric study concerning the use of combined cycle technologies for power generation and cost-benefit analysis was carried out using the independent power producers optimization algorithm in which the electricity unit cost was calculated by independent power producers in Cyprus [13]. Performance, cost, and emissions data for coal and natural gas-fired power plants were presented, based on information from studies carried out recently for the IEA Greenhouse Gas R\&D Program by major engineering contractors and process licensors [14]. A new methodology is presented for new design of power plants, which combines the benefits of thermodynamics, economics, and mathematical optimization [15]. In order to account for the cost of the investment required, the total capital cost must be placed on an annual basis. The annual cost consists due to interest accumulated on the investment, depreciation, maintenance, insurance, and taxes. The equipment life deteriorates with time and its depreciation cost is associated with it and thus, loses value [16].

This work presents the thermal and economic analysis of thermal power plant using thermodynamic analysis, and economic analysis based on Net present value approach. The predicted results agree with plant operating data.

\section{Coal-Fired Power Plant}

A schematic diagram of 210 MWe unit of a coal-fired power plant is shown in Figure 1. In power plants, several physical, chemical, and mechanical processes are conducted to transfer the energy, stored in fossil fuel, into electrical energy. This energy conversion is divided into several stages. Thermal power plant (Figure 5) uses coal as feedstock to convert it into mechanical energy through the expansion of steam from a high pressure in a suitable prime mover called steam turbine. Generator coupled with turbine produces electrical energy. Coal received from collieries in the rail wagons is mechanically unloaded by wagon tippler and transported by belt conveyor system to the boiler raw coal bunkers. The crushed coal, when not required for raw coal bunkers, is carried to coal storage area through belt conveyor and telescopic chute. The quantity of coal from coal bunkers to coal mill is regulated through raw coal chain feeder, where coal is pulverized into the fine powder form. The pulverized coal is then sucked by vapor fan and finally stored in the pulverized coal bunkers. The pulverized coal is then pushed to the boiler furnace, which is comprised of water tube walls all around through which water circulates. This chemically treated water running through the walls of boiler furnace gets evaporated at high temperature into steam by getting furnace heat. This steam is further heated in the superheater (SH). The superheated steam produced in the superheater enters into the high pressure Turbine (HPT). After expansion in HPT, cold reheat steam is divided into two streams, one is sent for reheating in reheater $(\mathrm{RH})$, and another is sent towards high pressure feedwater heater (HP-1). Steam then passes through intermediate pressure turbine (IPT) and low pressure turbine (LPT) respectively. The incoming stream of steam towards IPT from HPT after RH is divided into three streams. One is sent towards intermediate pressure feedwater heater (HP-2), and the other two are sent towards Deaerator (DR) and LPT respectively. Similarly the incoming stream of steam towards 
LPT from IPT is divided into four streams, and out of these four streams, three streams are sent towards low pressure feedwater heater (LP-1, LP-2 and LP-3) and one stream is sent towards condenser, respectively. The steam after doing useful work in the turbine is condensed in condenser. The condensate is sent by condensate extraction pumps (CEP) towards gland steam cooler (GSC), drain cooler (DC) and remaining is sent towards low pressure feedwater heaters. Since the extracted steam upon condensation gets subcooled so the drain cooler (DC) is used. From the last low pressure feedwater heater (LP-1) outlet, the condensate enters in deaerator shell. Boiler feed pump (BFP) supplies this condensate quantity from deaerator (DR) to Low Pressure Feedwater Heaters and High Pressure Feed Water Heaters respectively. Boiler feed pump (BFP) is a multistage pump provided for pumping feedwater (FW) to economizer. Three pumps each of $50 \%$ of total capacity are provided out of which two pumps work in parallel and third will be reserve. After HP-1 the condensate passes through economizer (ECO) and finally it enters into the boiler drum. Hence the cycle is completed.

\section{Thermodynamic Modeling}

Energy and mass balance equations have been used for the mathematical modeling of each component. The empirical relations have been also derived based on thermodynamic relations.

3.1. High Pressure Feedwater Heater (HP-1). High pressure feedwater heater receives superheated steam bled from the turbine at state 1 , the steam is first desuperheated then condensed and finally subcooled, whereas the feedwater gets heated as shown in Figure 2. The schematic diagram of high pressure feedwater heater "HP-1" (for $i=1$ ) is shown in Figure 3.

Mass balance:

$$
\sum x_{\text {in }}=\sum x_{\text {out }}
$$

Energy balance:

$$
\begin{gathered}
x_{i} \times h_{s(i)}+1 \times h_{f(i+1)}=1 \times h_{f(i)}+x_{i} \times h_{c(i)}, \\
x_{i}=\frac{\left(h_{f(i)}-h_{f(i+1)}\right)}{\left(h_{s(i)}-h_{c(i)}\right)},
\end{gathered}
$$

where $h_{f(i)}=h_{(i) l}-\mathrm{TTD} \times \mathrm{Cpw}$ and $h_{c(i)}=h_{f(i+1)}+$ ETD $\times$ Cpw. " $x$ " is the fractional mass flow with total steam flow from boiler. TTD and ETD are terminal and entry temperature difference of feedwater heaters. The value of TTD and ETD is taken to be $5^{\circ} \mathrm{C}$ and $2^{\circ} \mathrm{C}$, respectively. The pressure for each turbine extraction is supplied empirically using design data of $210 \mathrm{MWe}$ thermal power plants (see Table 1) as given by (3) as

$$
p_{i}=0.189 \mathrm{MWe}+1.476 .
$$

The formulations of high pressure feedwater heater (HP2) (Figure 13), deaerator (Figure 14), low pressure feedwater heaters (LP-1, LP-2, LP3) (Figures 15, 16, and 17), drain cooler (Figure 18), gland steam condenser (Figure 19), and ejector (Figure 20) are detailed in Appendix A.

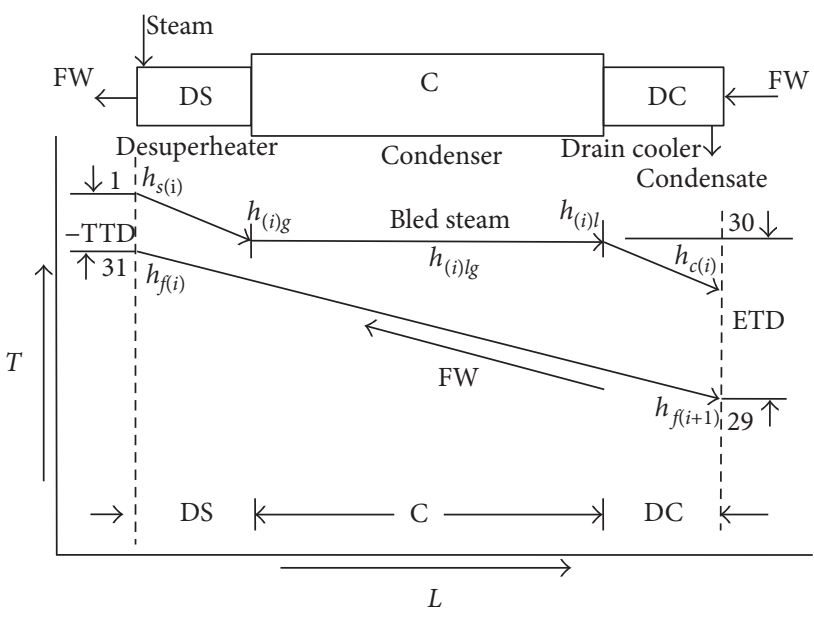

FIgURE 2: Temperature-length diagram for HP-1 (DS: desuperheater, C: condenser; DC: drain cooler).

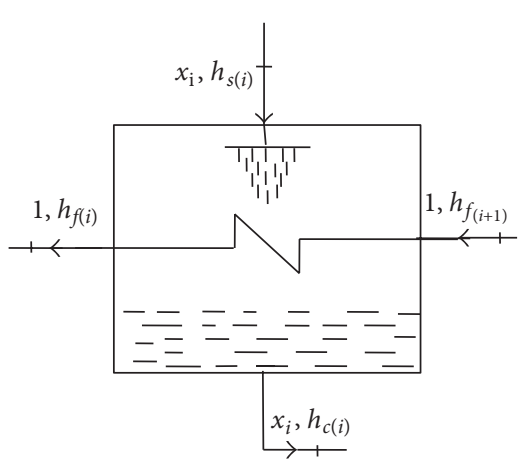

FIGURE 3: Schematic diagram of high pressure feedwater heater (HP1).

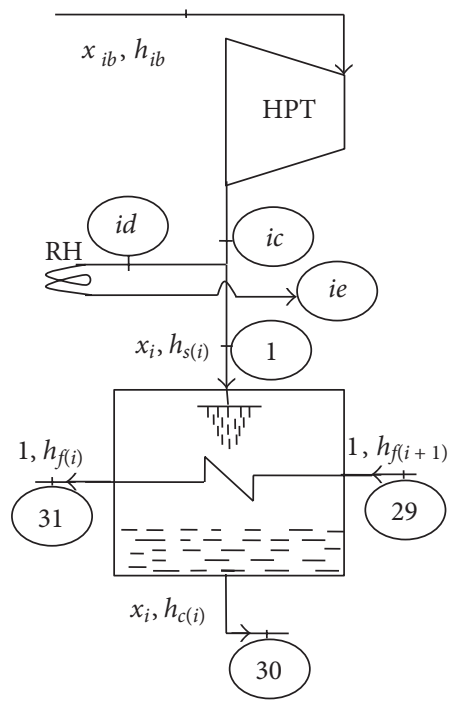

FIGURE 4: Schematic diagram of turbine-cum-high pressure feedwater heater. 
TABLE 1: Design data of pressure (bar) of bled stream at various locations from turbine.

\begin{tabular}{|c|c|c|c|c|c|c|c|}
\hline \multirow{2}{*}{ Sr. no. } & \multirow{2}{*}{ MWe } & \multicolumn{6}{|c|}{ Pressure (bar) of bled stream from the turbine } \\
\hline & & $P_{1}$ & $P_{2}$ & $P_{3}$ & $P_{4}$ & $P_{5}$ & $P_{6}$ \\
\hline 1. & 126 & 25.36 & 10.60 & 4.37 & 1.589 & 0.558 & 0.288 \\
\hline 2. & 168 & 33.26 & 13.84 & 5.28 & 1.961 & 0.695 & 0.356 \\
\hline 3. & 210 & 41.27 & 16.25 & 6.43 & 2.396 & 0.853 & 0.431 \\
\hline
\end{tabular}

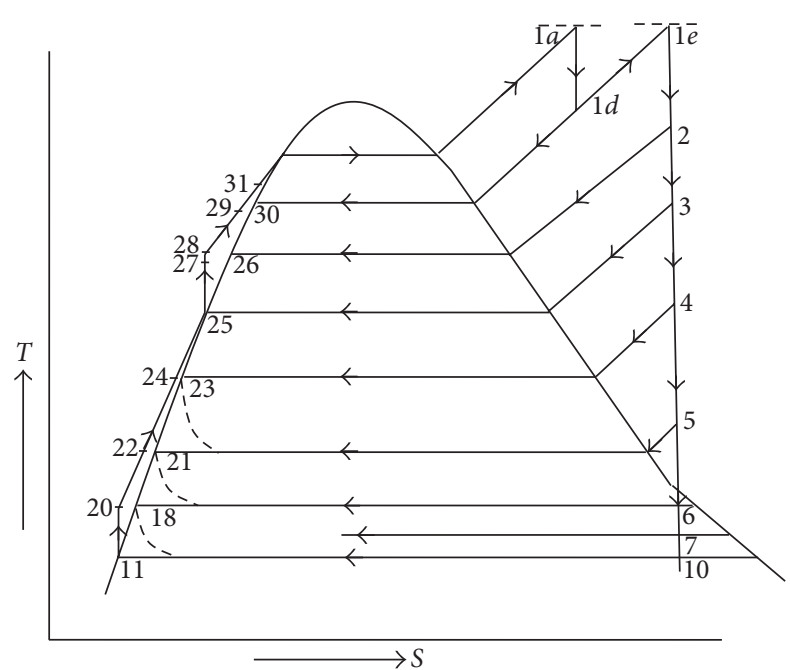

FIGURE 5: T-S diagram of thermal power plant.

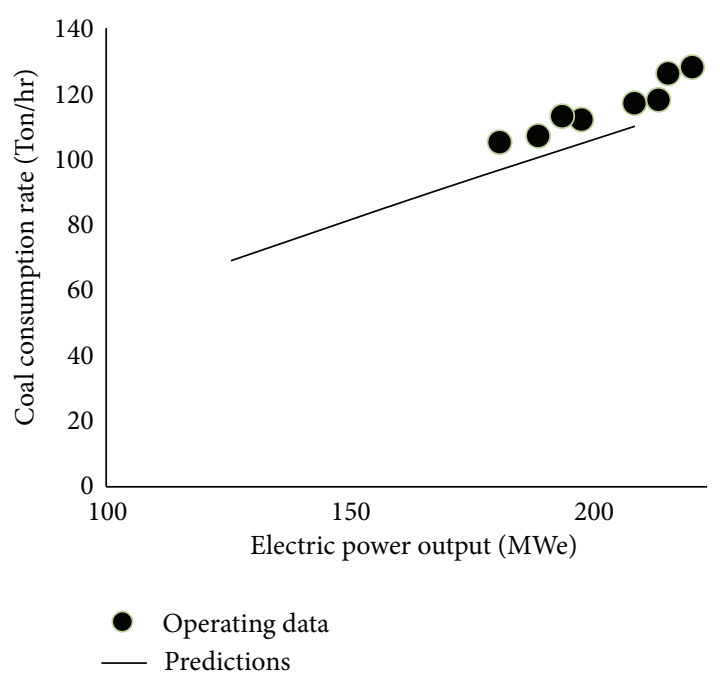

FIGURE 6: Coal consumption (T/hr) versus plant output.

3.2. Steam Turbine. A steam turbine is one module that extracts thermal energy from pressurized steam and converts it into useful mechanical work. Steam turbine is condensing, tandem compounded, horizontal, reheat type, and single shaft machine. It has got separate high pressure, and intermediate and low-pressure parts. The HP part is a single cylinder and IP \& LP parts are double flow cylinders. The condensate which is leaving the first HP-1 feedwater heater is mixed with the subsequent feedwater heater and then the total condensate is mixed with the next closed feedwater

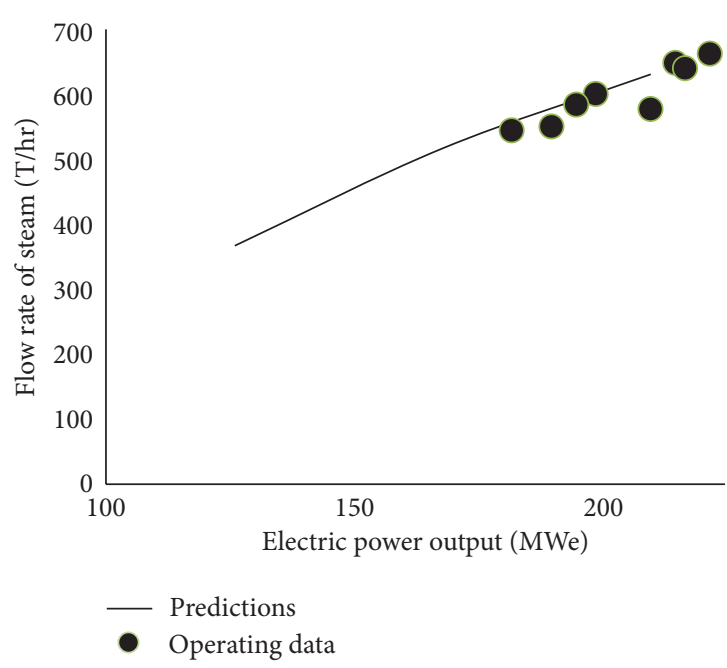

Figure 7: Mass flow rate of steam versus plant output.

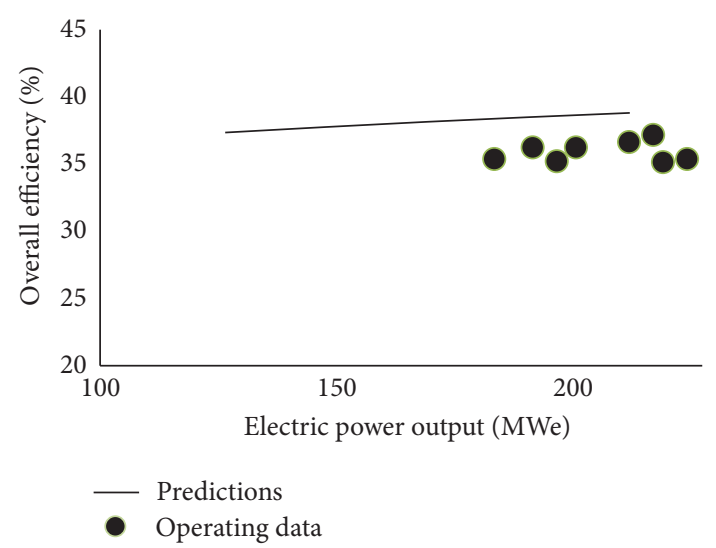

Figure 8: Overall efficiency versus plant output.

heater and then the resultant is normally dumped into the deaerator. In the modern thermal power plants, the modeling of steam turbine is carried out along with feedwater heaters. Thus, steam turbine-feedwater heater can be treated as mathematical element to describe the thermal power plant. The schematic diagram of steam turbine-cum-high pressure feedwater heater is shown in Figure 4.

Thus, the power output of the turbine can be written in terms of mass flow rate of working substance and enthalpy drop as

$$
P_{o p}=m_{w} \Delta h,
$$

where $\Delta h=h_{\text {in }}-h_{\text {out }}$. 


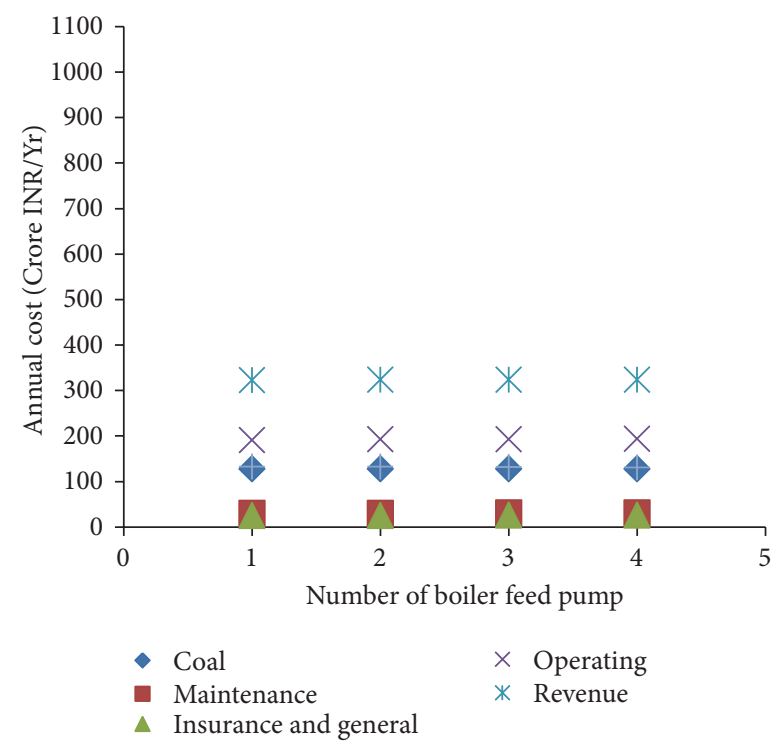

FIGURE 9: Annual cost (Crore INR/Yr) versus number of boiler feed pump.

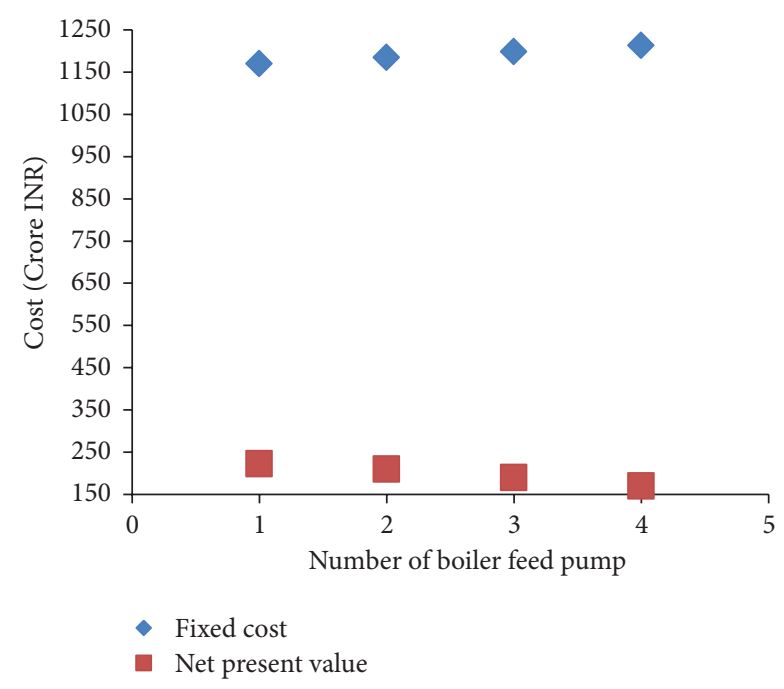

Figure 10: Cost (Crore INR) versus number of boiler feed pump.

Mass balance:

$$
\begin{gathered}
x_{1 b}=\sum_{k=1}^{2} x_{B_{k}}+\sum_{k=1}^{2} x_{C_{k}}+\sum_{k=1}^{2} x_{d_{k}}+x_{1 c}, \\
x_{1 c}=x_{1 d}+x_{1 e} .
\end{gathered}
$$

The notation of subscripts $B_{k}, C_{k}, d_{k} 1 c, 1 d$, and $1 e$ represents the various states in Figure 1.

Work done:

$$
W_{t 1}=x_{1 b}\left(h_{1 b}-h_{1 c}\right) .
$$

Accordingly, formulation of intermediate and low pressure turbine can be done and final work can be written as

$$
W_{t}=W_{t 1}+W_{t 2}+W_{t 3} \text {. }
$$

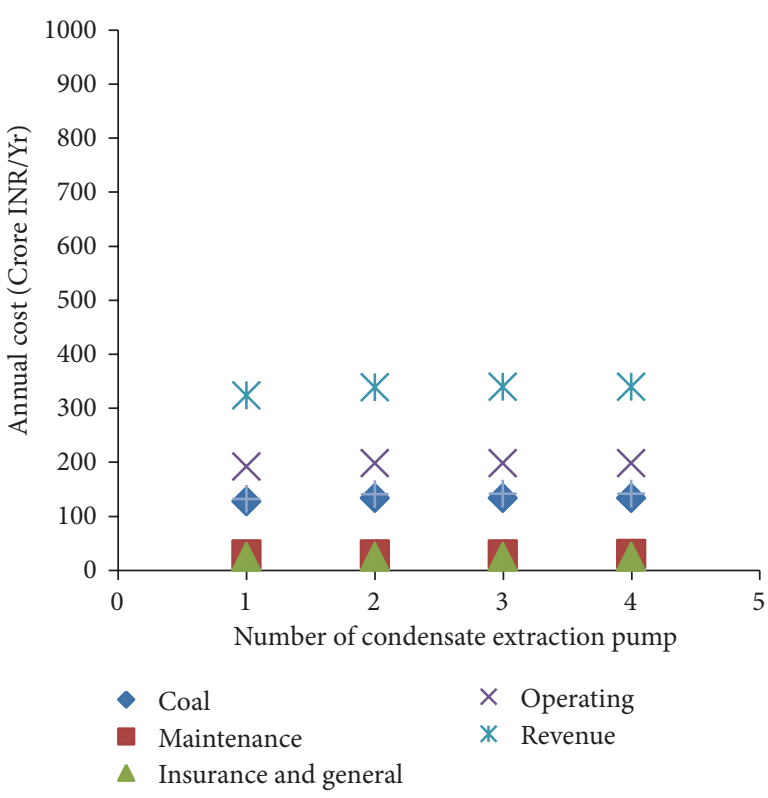

FIGURE 11: Annual cost (Crore INR/Yr) versus number of condensate extraction pump.

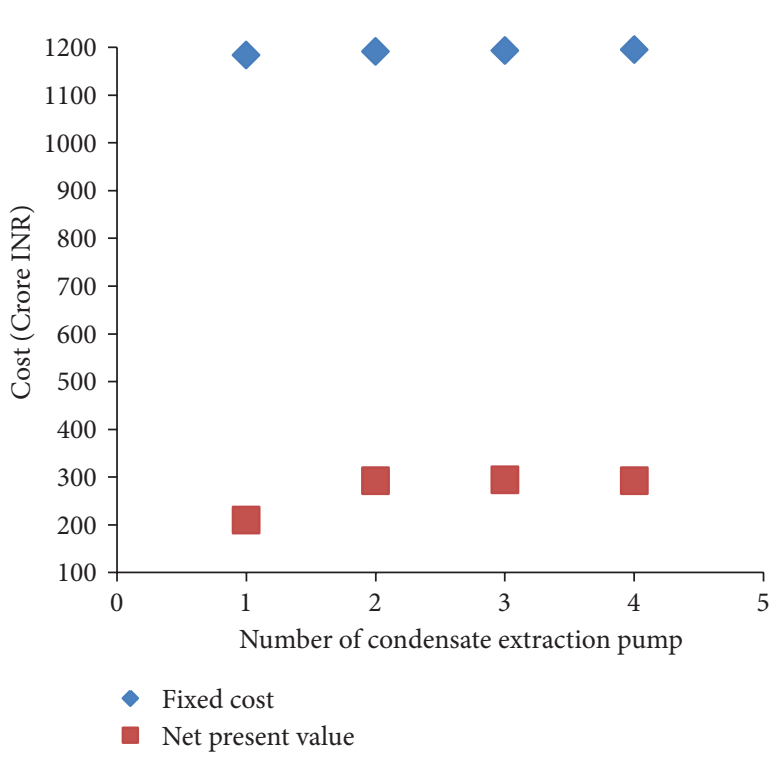

FIgURE 12: Cost (Crore INR) versus number of condensate extraction pump.

3.3. Condenser. In the analysis, it was assumed that the balance steam from turbine after subtraction of bleeds is condensed all in condenser. Thus mass balance can be written as

$$
\begin{gathered}
x_{10 a}=x_{10}+\sum_{k=1}^{6} x_{B_{k}}, \\
x_{11}=x_{10 a}+x_{11 b} .
\end{gathered}
$$




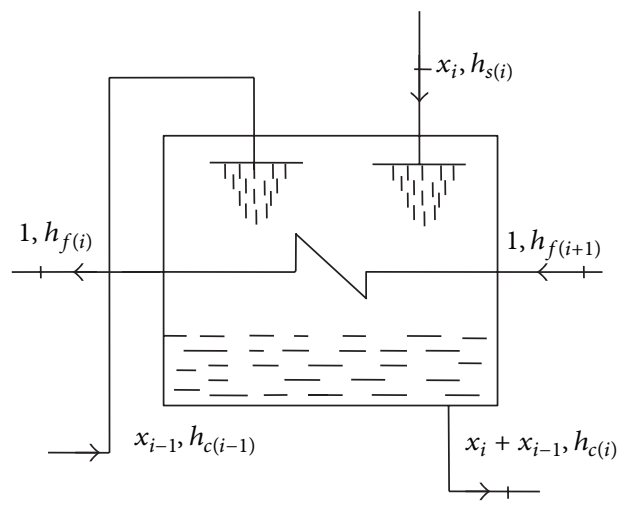

FIGURE 13: Mass and energy balance for high pressure feedwater heater (HP-2).

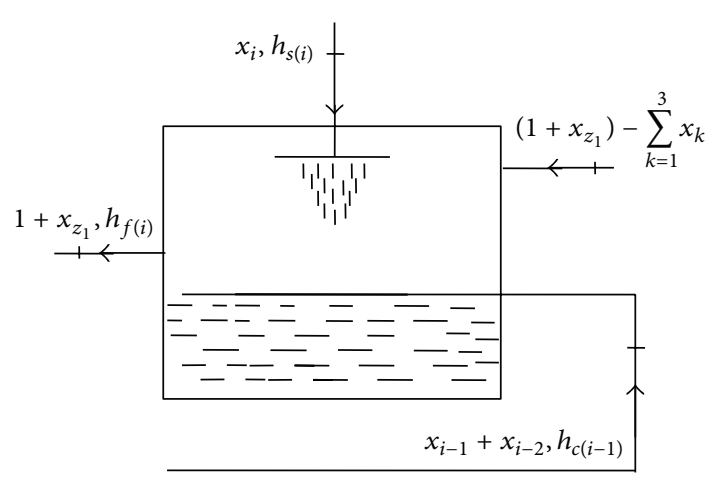

FIGURE 14: Mass and energy balance for deaerator (DR).

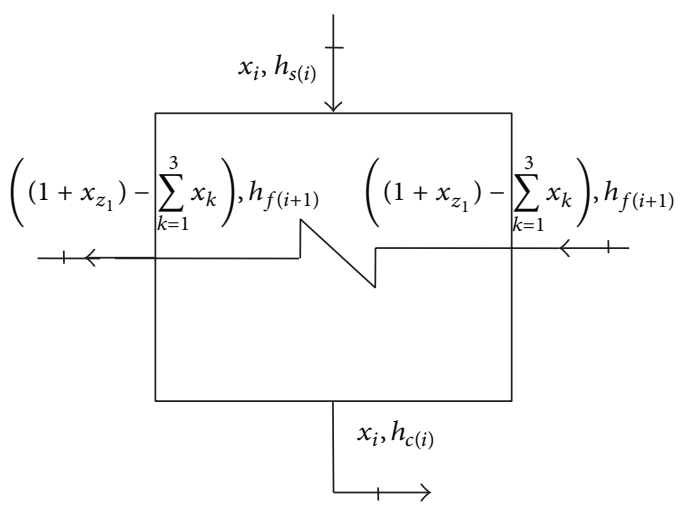

Figure 15: Mass and energy balance for low pressure feedwater heater (LP-1).

Mass consumption rate of coal can be written in terms of unit mass flow rate of water $\left(m_{\mathrm{uw}}\right)$ as

$$
m_{\text {coal }}=\frac{m_{\mathrm{uw}}\left(x_{1 a}\left(h_{1 a}-h_{31}\right)+x_{1 d}\left(h_{1 e}-h_{1 d}\right)\right)}{\left(\eta_{\text {boiler }} \mathrm{CV}_{\text {coal }}\right)} .
$$

$\eta_{\text {boiler }}$ is the boiler efficiency; it is fixed at 0.86 in the present calculations [17].

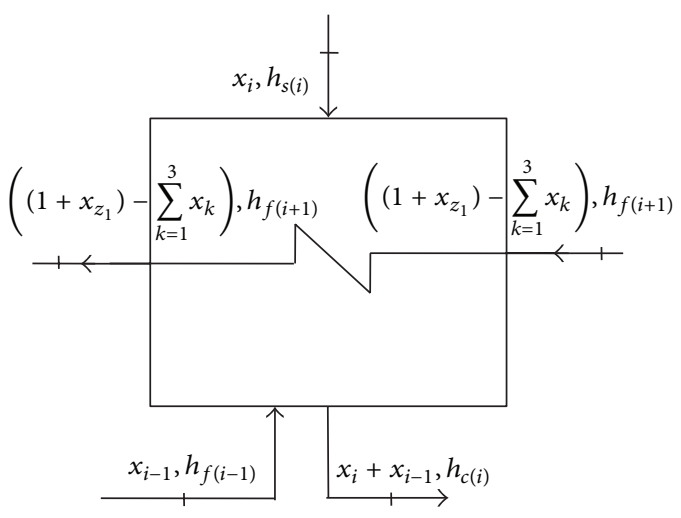

FIGURE 16: Mass and energy balance for low pressure feedwater heater (LP-2).

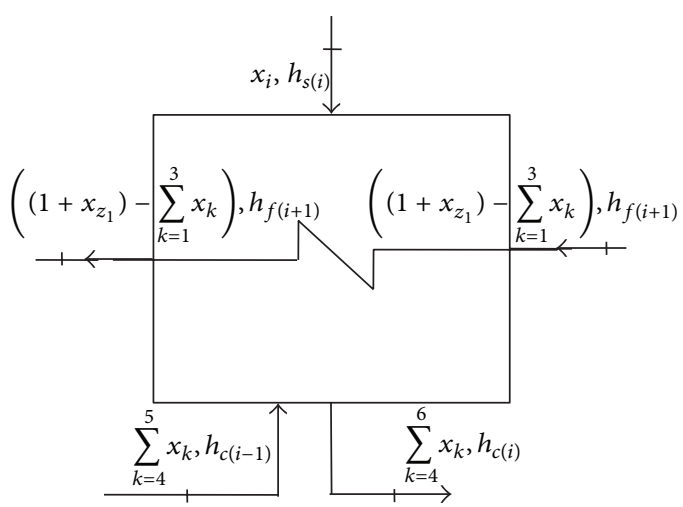

FIGURE 17: Mass and energy balance for low pressure feedwater heater (LP-3).

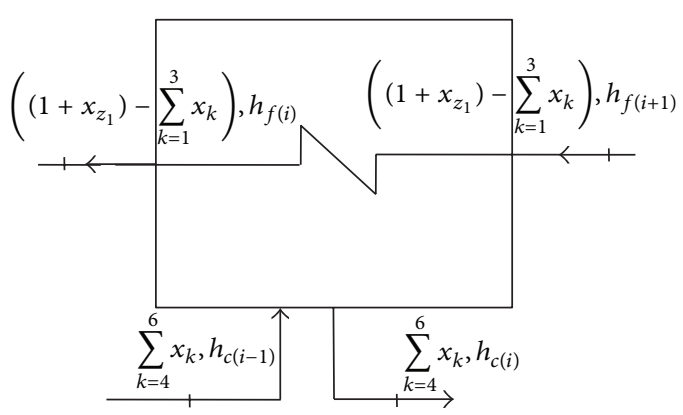

FIGURE 18: Mass and energy balance for drain cooler (DC).

The overall plant efficiency can be defined in terms of plant capacity (MWe) as

$$
\eta_{\text {plant }}=1000 \times \frac{\mathrm{MWe}}{\left(m_{\text {coal }} \times \mathrm{CV}_{\text {coal }}\right)} .
$$

\section{Economic Analysis}

The economic analysis of the plant has been carried out on the basis of initial capital investment, operating costs, and annual revenue. The equipment cost include boiler, steam turbine, condenser, generator, and auxiliary equipment such 


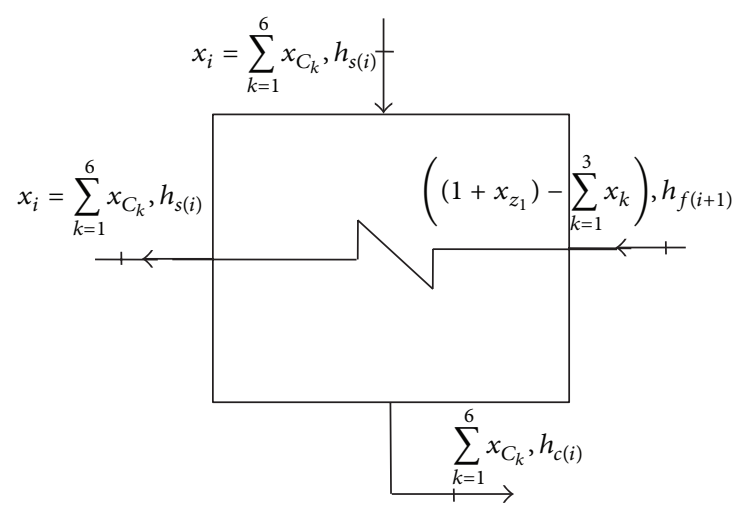

FIGURE 19: Mass and energy balance for gland steam condenser (GSC).

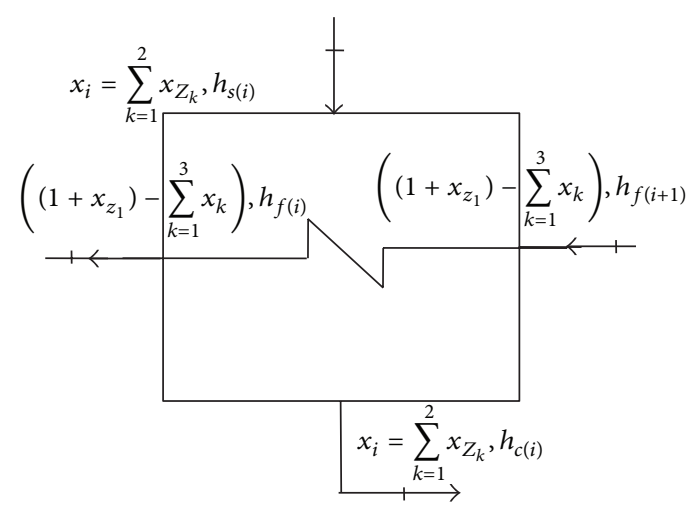

Figure 20: Mass and energy balance for ejector (EJE).

as condensate extraction pump, feed water pump, and so forth. Thus, fixed (equipment) cost, $C_{F}$, can be written in terms of redundancies of respective components (if any) as

$$
\begin{gathered}
C_{F}=f\left(C_{\text {boiler }}+C_{\text {turbine }}+C_{\text {condenser }}+n_{\text {ce }}\left(C_{\text {condpump }}\right)\right. \\
\left.+n_{\mathrm{fb}}\left(C_{\text {boilerfeedpump }}\right)+C_{\text {generator }}\right) .
\end{gathered}
$$

$C_{F}$ represents fixed cost. The coal storage, ash handling, electrical works, civil works, and fumes treatment costs are neglected in the present work. The initial cost for each equipment/component $C_{F i}$ has been obtained from [11] empirically in following form

$$
C_{F i}=a(\mathrm{MWe})^{b},
$$

where the values of constants $a$ and $b$ are taken from Table 2.

The total operating costs include maintenance, insurance, and general costs, total operating labor, and purchase of coal feedstock as [11]

$$
C_{\mathrm{OP}}=\left(C_{\text {maint }}+C_{\text {ins }}+n_{L} C_{\text {lab }}+m_{\text {coal }} C_{\text {coal }}\right),
$$

where $C$ is cost in (INR), while subscripts OP, maint, ins, coal, ep, and lab correspond to operating, maintenance, insurance,
TABLE 2: Constants for purchased equipment cost estimation [11].

\begin{tabular}{lcc}
\hline Equipments & $a$ & $b$ \\
\hline Generator & 138300 & 0.6107 \\
Steam turbine & 633000 & 0.398 \\
Condensate extraction pumps & 9000 & 0.4425 \\
Steam boiler & 1340000 & 0.694 \\
Boiler feed pumps & 35000 & 0.6107 \\
Condenser & 398000 & 0.333 \\
\hline
\end{tabular}

TABLE 3: Operating data for calculating average salary of plant personnel in a typical $210 \mathrm{MWe}$ plant unit.

\begin{tabular}{lcc}
\hline $\begin{array}{l}\text { Total personnel deployed } \\
\text { in } 210 \text { MWe unit }\end{array}$ & $\begin{array}{c}\text { Total monthly salary } \\
\text { of personnel (Rs.) }\end{array}$ & $\begin{array}{c}\text { Average monthly } \\
\text { salary (Rs.) }\end{array}$ \\
\hline 233 & 6025000 & 25858.36 \\
\hline
\end{tabular}

coal feedstock, electricity/MWe, and individual labour cost, respectively. Here maintenance and insurance costs are taken to be $3 \%$ and $2.5 \%$ of the total fixed cost [11]. Average personnel salary on annual basis is deduced from plant data as given in Table 3 .

Annual revenue obtained from the electricity can be evaluated as

$$
R_{\mathrm{an}}=f_{\mathrm{MWe}} \times \mathrm{hrs} \times \mathrm{MWe} \times C_{\mathrm{ep}} .
$$

Thus, Net present value (NPV) can be written as

$$
\mathrm{NPV}=\sum_{l=1}^{p l} \frac{\left(R_{\mathrm{an}}-C_{\mathrm{OP}}\right)_{l}}{(1+D)^{l}}-C_{F}
$$

All reference values of data collected for the analysis are tabulated in Table 4. The taxes and financial charges have been neglected in this work.

\section{Results and Discussion}

The above analysis was used to predict the coal consumption rate, overall thermal efficiency, mass flow rate of steam through boiler, and Net present value of thermal power plant for given plant capacity and redundancy on pumps. The predictions of mass flow rate, overall plant efficiency, and coal consumption rate were compared with operating plant data from plant for validation as shown in Figures 6, 7, and 8. The coal consumption rate and mass flow rate of steam increase with electric power output of plant. However, overall efficiency is not showing any significant increase with electric power output. A fair agreement between predictions and operating data has been shown graphically at wide range of load conditions of plant.

The effect of employing redundancy (excessive) units to boiler feed pumps and condensate extraction pump on annual cost of plant and Net present value is shown in Figures $9,10,11$, and 12 , which reflects that equipment, maintenance, 
TABLE 4: Input data collected from literature and plant records.

\begin{tabular}{|c|c|c|c|c|c|c|c|c|c|c|}
\hline Parameter & $n_{L}$ & Lab & $C_{\text {coal }}$ & $\mathrm{CV}_{\text {coal }}$ & $f$ & $\mathrm{pl}$ & $C_{\mathrm{ep}}$ & $f_{\text {Mwe }}$ & $D$ & $\mathrm{hrs} / \mathrm{yr}$ \\
\hline Value & 233 & 25858.36 (INR) & 2696.81 (INR/Tone) & $17656(\mathrm{~kJ} / \mathrm{kg})$ & 1.87 & 20 (year) & 4000 (Rs/MW-hr) & 0.9 & $9 \%$ & 4555 \\
\hline
\end{tabular}

insurance, operating, coal, and revenue increase with any increase in pump redundancy in various subsystems. The Net present value decreases with any addition of boiler feed pump redundancy in water circulation subsystem (Figure 10), while it shows marginally increasing trend with condensate extraction pump redundancy in condenser unit (Figure 12).

The effect of condensate extraction pump redundancy on Net present value is comparatively higher as compared with case of boiler feed pump. It is expected due to lower initial cost of condensate extraction pump as compared with the cost of boiler feed pump.

\section{Conclusions}

The thermal and economic analysis of a 210 MWe coal-fired power plant was carried out to predict the coal consumption rate, overall thermal efficiency, mass flow rate of steam through boiler, and Net present value of thermal power plant for given plant load and redundancy of boiler feed pump and condensate extraction pump. Thermodynamic modeling was carried out for evaluating the thermal performance. Predictions of mass flow rate of steam, coal consumption rate, and thermal efficiency were compared against plant operating data for validation. Economic analysis includes equipment cost, fuel cost, operations and maintenance cost, revenue, and plant Net present value. The redundancy due to condensate extraction pump is sensitive to Net present value.

\section{Appendix}

\section{A. High Pressure Feedwater Heater (HP-2)}

In the same manner for $i=2$,

Energy balance:

$$
x_{i}=\frac{\left(h_{f(i)}-h_{f(i+1)}\right)}{\left(h_{s(i)}-h_{c(i)}\right)}+x_{i-1}\left(\frac{\left(h_{c(i)}-h_{c(i-1)}\right)}{\left(h_{s(i)}-h_{c(i)}\right)}\right) \text {. }
$$

Empirical relations:

$$
\begin{gathered}
p_{i}=0.077 \times \mathrm{MWe}+0.83, \\
h_{f(i)}=h_{(i) l}-\mathrm{TTD} \times \mathrm{Cpw}, \\
h_{c(i)}=h_{f(i+1)}+\mathrm{ETD} \times \mathrm{Cpw} .
\end{gathered}
$$

\section{B. Deaerator (DR)}

Energy balance, for $i=3$ :

$$
\begin{gathered}
x_{i}=\left(\left(1+x_{z_{1}}\right) \times \frac{\left(h_{f(i)}-h_{f(i+1)}\right)}{\left(h_{s(i)}-h_{f(i+1)}\right)}\right) \\
-\left(\left(x_{i-1}+x_{i-2}\right) \times \frac{\left(h_{c(i-1)}-h_{f(i+1)}\right)}{\left(h_{s(i)}-h_{f(i+1)}\right)}\right) \\
p_{i}=0.0312 \times \mathrm{MWe}+0.4367 .
\end{gathered}
$$

\section{Low Pressure Feedwater Heater (LP-1)}

Energy balance, for $i=4$ :

$$
\begin{gathered}
x_{i}=\frac{\left(\left(\left(1+x_{z_{1}}\right)-\sum_{k=1}^{3} x_{k}\right) \times\left(h_{f(i)}-h_{f(i+1)}\right)\right)}{\left(h_{s(i)}-h_{c(i)}\right)}, \\
p_{i}=0.0111 \times \mathrm{MWe}+0.189, \\
h_{f(i)}=h_{(i) l}-\mathrm{TTD} \times \mathrm{Cpw}, \\
h_{c(i)}=h_{(i) l}-\mathrm{ETD} \times \mathrm{Cpw} .
\end{gathered}
$$

\section{Low Pressure Feedwater Heater (LP-2)}

Energy balance, for $i=5$ :

$$
\begin{gathered}
x_{i}=\left(\frac{\left(\left(1+x_{z_{1}}\right)-\sum_{k=1}^{3} x_{k}\right) \times\left(h_{f(i)}-h_{f(i+1)}\right)}{\left(h_{s(i)}-h_{c(i)}\right)}\right) \\
+\left(x_{i-1} \times \frac{\left(h_{c(i)}-h_{f(i-1)}\right)}{\left(h_{s(i)}-h_{c(i)}\right)}\right), \\
p_{i}=0.00405 \times \mathrm{MWe}+0.048, \\
h_{f(i)}=h_{(i) l}-\mathrm{TTD} \times \mathrm{Cpw}, \\
h_{c(i)}=h_{(i) l}-\mathrm{ETD} \times \mathrm{Cpw} .
\end{gathered}
$$

\section{E. Low Pressure Feedwater Heater (LP-3)}

Energy balance, for $i=6$ :

$$
\begin{gathered}
x_{i}=\left(\frac{\left(\left(1+x_{z_{1}}\right)-\sum_{k=1}^{3} x_{k}\right) \times\left(h_{f(i)}-h_{f(i+1)}\right)}{\left(h_{s(i)}-h_{c(i)}\right)}\right) \\
+\left(\sum_{k=4}^{5} x_{k} \times \frac{\left(h_{c(i)}-h_{c(i-1)}\right)}{\left(h_{s(i)}-h_{c(i)}\right)}\right), \\
p_{i}=0.00198 \times \mathrm{MWe}+0.039,
\end{gathered}
$$




$$
\begin{aligned}
& h_{f(i)}=h_{(i) l}-\mathrm{TTD} \times \mathrm{Cpw}, \\
& h_{c(i)}=h_{(i) l}-\mathrm{ETD} \times \mathrm{Cpw} .
\end{aligned}
$$

\section{F. Drain Cooler (DC)}

Energy balance, for $i=7$ :

$$
h_{f(i)}=\left(\sum_{k=4}^{6} x_{k} \times \frac{\left(h_{c(i-1)}-h_{c(i)}\right)}{\left(\left(1+x_{z_{1}}\right)-\sum_{k=1}^{3} x_{k}\right)}\right)+h_{f(i+1)} .
$$

\section{G. Gland Steam Condenser (GSC)}

Energy balance, for $i=8$ :

$$
h_{f(i)}=\left(\sum_{k=1}^{6} x_{C_{k}} \times \frac{\left(h_{s(i)}-h_{c(i)}\right)}{\left(\left(1+x_{z_{1}}\right)-\sum_{k=1}^{3} x_{k}\right)}\right)+h_{f(i+1)} \text {. }
$$

\section{H. Ejector (EJE)}

Energy balance, for $i=9$ :

$$
h_{f(i)}=\left(\sum_{k=1}^{2} x_{z_{k}} \times \frac{\left(h_{s(i)}-h_{c(i)}\right)}{\left(\left(1+x_{z_{1}}\right)-\sum_{k=1}^{3} x_{k}\right)}\right)+h_{f(i+1)} \text {. }
$$

\section{Nomenclature}

$$
\begin{aligned}
& C_{\text {coal }}: \text { Coal cost (INR/tone) } \\
& c_{e}: \quad \text { Condensate extraction pump } \\
& \mathrm{CV}_{\text {coal }} \text { : Calorific value of coal }(\mathrm{kJ} / \mathrm{kg}) \\
& D \text { : Discount rate }(\% / y r) \\
& f \text { : } \quad \text { Factor for direct installation, auxiliary, } \\
& \text { instrumentation and control, engineering, } \\
& \text { and plant start-up } \\
& f_{\mathrm{MWe}}: \% \text { of net electric energy power plant } \\
& \text { output assumed as } 90 \% \text { of MWe available } \\
& \text { for sale } \\
& x_{i} \text { : } \quad \text { Fractional mass flow rate of steam at " } i \text { th" } \\
& \text { state (tone/hr) } \\
& h_{s(i)}: \quad \text { Enthalpy of superheated steam }(\mathrm{kJ} / \mathrm{kg}) \\
& h_{f(i)}: \quad \text { Enthalpy of feedwater at exit }(\mathrm{kJ} / \mathrm{kg}) \\
& h_{f(i+1)} \text { : Enthalpy of feedwater at entry }(\mathrm{kJ} / \mathrm{kg}) \\
& h_{c(i)}: \quad \text { Enthalpy of condensate }(\mathrm{kJ} / \mathrm{kg}) \\
& m_{\text {coal }} \text { : Annual coal consumption (tone/hr) } \\
& \text { hrs: Annual operating hours of the plant } \\
& \text { (hrs/yr) } \\
& n_{\text {ce }} \text { : Number of sub-systems (redundancy) of } \\
& \text { condensate extraction pumps } \\
& n_{\mathrm{fb}} \text { : Number of sub-systems (redundancy) of } \\
& \text { boiler feed pumps } \\
& n_{L} \text { : Total number of employed personnel }
\end{aligned}
$$

$P_{i}: \quad$ Pressure of bled steam from turbine at " $i$ th" state (bar)

pl: $\quad$ Plant life (years)

$P_{\text {npv }}:$ (INR)

$R_{\text {an }}$ : Annual revenue earned (INR/yr)

$f_{b}$ : Boiler feed pump

$\eta_{\text {plant }}:$ Overall thermal efficiency of the plant (\%).

\section{Conflict of Interests}

The authors declare that they have no conflict of interests regarding the publication of this paper.

\section{References}

[1] R. W. Haywood, "A generalized analysis of the regenerative steam cycle for a finite number of heaters," Proceedings of the Institution of Mechanical Engineers A, vol. 161, pp. 157-164, 1949.

[2] C. D. Weir, "Optimization of heater enthalpy rises in feed-heating trains," Proceedings of the Institution of Mechanical Engineers A, vol. 174, pp. 769-796, 1960.

[3] J. H. Horlock, "Simplified analyses of some vapour power cycles," Proceedings of the Institution of Mechanical Engineers A, vol. 210, no. 3, pp. 191-202, 1996.

[4] G. Angelino, C. Invernizzi, and G. Molteni, "The potential role of organic bottoming rankine cycles in steam power stations," Proceedings of the Institution of Mechanical Engineers, vol. 213, no. 2, pp. 75-81, 1999.

[5] A. Kostyuk and V. Frolov, Steam and Gas Turbines, Mir Publishers, Moscow, Russia, 1985.

[6] M. Ameri, P. Ahmadi, and A. Hamidi, "Energy, exergy and exergoeconomic analysis of a steam power plant: a case study," International Journal of Energy Research, vol. 33, no. 5, pp. 499512, 2009.

[7] D. S. Remer and A. P. Nieto, "A compendium and comparison of 25 project evaluation techniques. Part 1: net present value and rate of return methods," International Journal of Production Economics, vol. 42, no. 1, pp. 79-96, 1995.

[8] S. Boonnasa and P. Namprakai, "Sensitivity analysis for the capacity improvement of a combined cycle power plant (100600 MW)," Applied Thermal Engineering, vol. 28, no. 14-15, pp. $1865-1874,2008$.

[9] A. C. Caputo and P. M. Pelagagge, "RDF production plants: II. Economics and profitability," Applied Thermal Engineering, vol. 22, no. 4, pp. 439-448, 2002.

[10] B. C. Giri and T. Dohi, "Optimal lot sizing for an unreliable production system based on net present value approach," International Journal of Production Economics, vol. 92, no. 2, pp. 157167, 2004.

[11] A. C. Caputo, M. Palumbo, P. M. Pelagagge, and F. Scacchia, "Economics of biomass energy utilization in combustion and gasification plants: effects of logistic variables," Biomass and Bioenergy, vol. 28, no. 1, pp. 35-51, 2005.

[12] R. Madlener and S. Stoverink, "Power plant investments in the Turkish electricity sector: a real options approach taking into account market liberalization," Applied Energy, vol. 97, pp. 124134, 2012.

[13] A. Poullikkas, "Parametric study for the penetration of combined cycle technologies into Cyprus power system," Applied Thermal Engineering, vol. 24, no. 11-12, pp. 1697-1707, 2004. 
[14] J. Davison, "Performance and costs of power plants with capture and storage of $\mathrm{CO}_{2}$," Energy, vol. 32, no. 7, pp. 1163-1176, 2007.

[15] J. Manninen and X. X. Zhu, "Thermodynamic analysis and mathematical optimisation of power plants," Computers and Chemical Engineering, vol. 22, supplement 1, no. 1, pp. S537S544, 1998.

[16] M. Peters, K. Timmerhaus, and R. West, Plant Design and Economics for Chemical Engineers, McGraw-Hill, New York, NY, USA, 1991.

[17] Thermal Power Plant Efficiency and Performance Monitoring, National Power Training Institute (NPTI), Faridabad, India, 2000. 

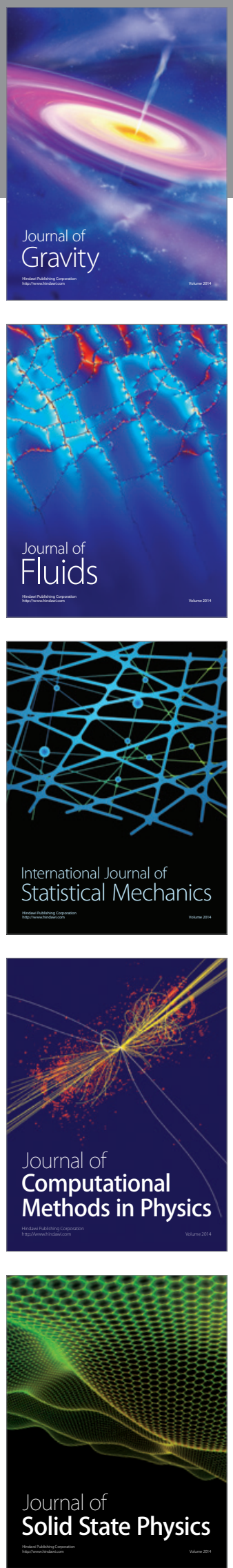

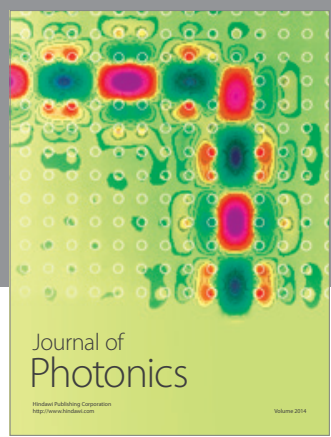

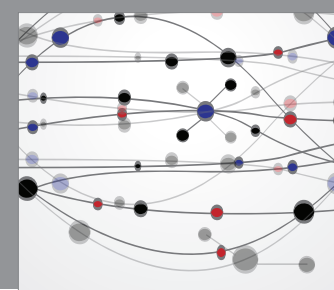

The Scientific World Journal

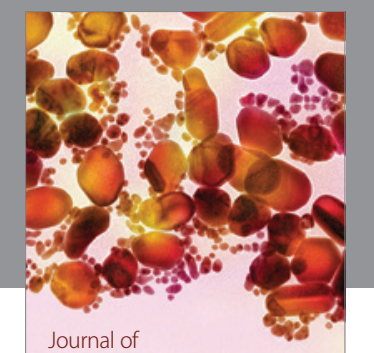

Soft Matter
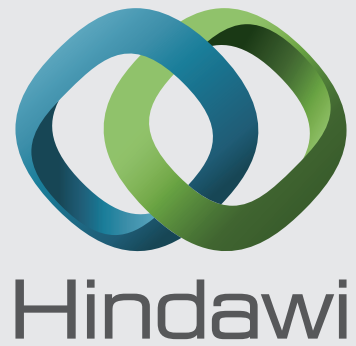

Submit your manuscripts at

http://www.hindawi.com
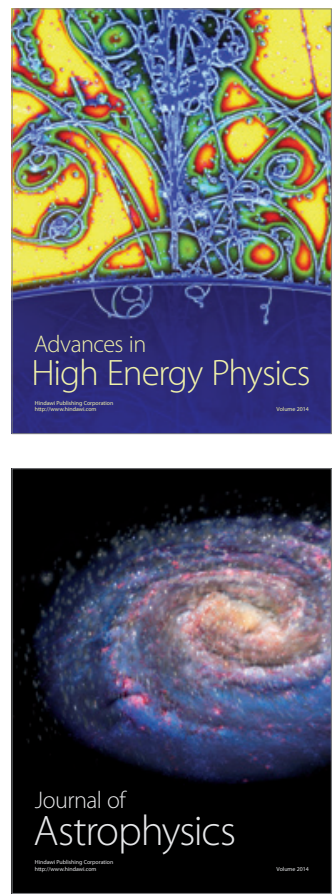
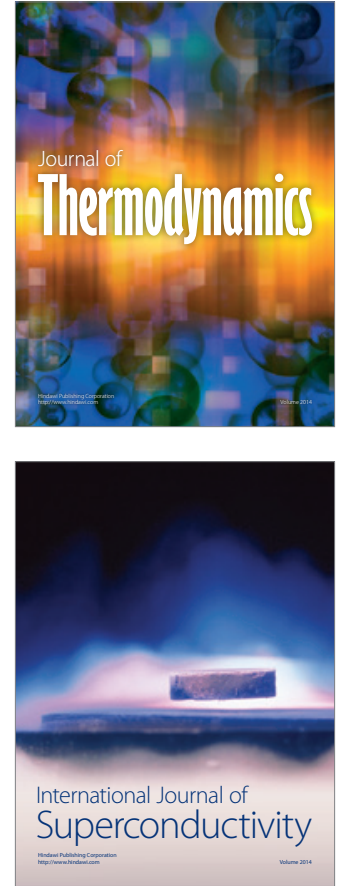
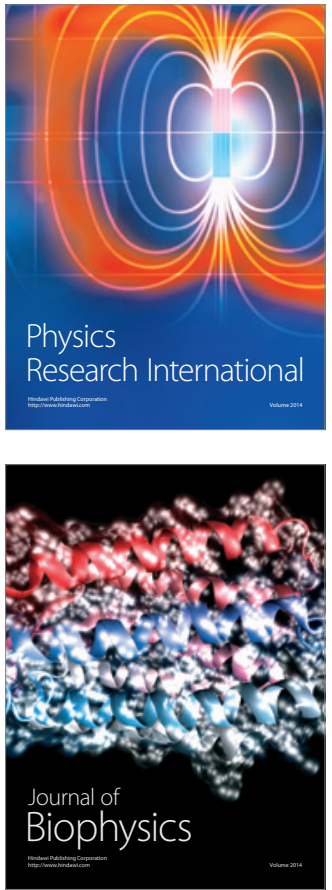
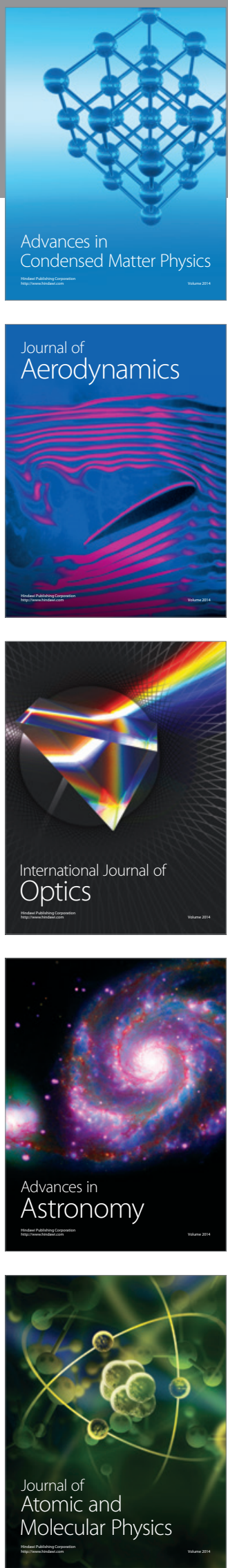